\title{
COMMUNITY-BASED TOURISM AND DEVELOPMENT IN THIRD WORLD COUNTRIES: THE CASE OF THE BAMILEKE ZONE OF CAMEROON AND THE INFLUENCE OF TRADITIONAL INSTITUTIONS
}

\author{
TERENCIA NGONO MINDZENG \\ University Lyon 2, France
}

\begin{abstract}
Community-based tourism, a sustainable tourism approach, is widely adopted as a means to improve the living conditions of local communities in Third World countries. One of the main driver that makes community-based tourism a tool for development is its principle of interconnection and action between the endogenous and exogenous forces within the tourism destination. This driving force can bolster community participation, community development and capacity-building. It is the combination of these three aspects that bring about "place revitalisation". Place revitalisation is paramount to development in the challenging context of Third World countries because it triggers local initiatives and empowerment. However, for the principle of exogenous and endogenous interconnection to be effective, it requires the existence of a well-established endogenous local institution within the host communities as well as a function transfer brought by the tourists and non-governmental institutions who are the exogenous forces to the destination. This paper seeks to assess the relevance of the principle of exogenous and endogenous interconnection to the enhancement of development in Third World countries. The research also examines the influence played by rural traditional institutions in this principle. The case study for this research is the Bamiléké zone, the breeding ground of community-based tourism initiatives in Cameroon, in which local institutions are very active in community development initiatives through community-based tourism.
\end{abstract}

Keywords: community-based tourism, development, local communities, place revitalisation, Third World countries, traditional institutions.

\section{INTRODUCTION}

Tourism has democratised itself to become a global phenomenon that is difficult to quantify. Its significant contribution to world economies and its resilience to economic and social upheavals, as well as geopolitical crisis, have encouraged its adoption by international organisations and national governments in economic development mechanisms.

Today's tourism challenge is to successfully grasp the benefits and risks of its exponential growth in a world that is weakened by the impacts of growing tourist pressure on its environment. Tourism is subjected to a social and economic disparity between the northern and southern hemisphere. This social and economic unevenness is evident through the enrichment of regions from the northern hemisphere and the growing impoverishment of the regions of the southern hemisphere, exacerbated by the wide disparity in the management and redistribution of world resources. This disparity, which affects tourism, has had consequences amongst the local communities of Third World countries. Such consequences include the huge reliance on tourism as a mono-activity that is dependent on geopolitical and macro-economic conditions [1] which are beyond the control of the local communities, and a tourism activity that is designed solely to satisfy the pressing needs of tourists, to the detriment of the local communities [2]. This, in turn, engenders frustrations and conflicts to occur amongst the local communities due to a lack of consideration for their needs and desires by the local authorities in the conception of tourism policies and activities. Also, the 
commoditisation of these communities and their traditional heritage for tourists are a cause for concern.

This ambivalent characteristic of the tourism phenomenon between the northern and the southern hemisphere has raised the curiosity of many researchers on tourism's capacity to alleviate the living conditions of the local communities of Third World countries. Some researchers associate tourism with a proletarian dependency between rich and poor countries: some believe that choosing tourism as a means for economic development is accepting a reliance upon the countries from where the tourists originate and, worst still, the deterioration of man and his environment. Others state that the rise of tourism in Third World countries will be difficult, precarious and always uncertain because of its extreme reliance on foreign requests [3].

These various reflections lead us to a crucial observation: tourism is an exogenous activity that integrates itself within the endogenous environment of the host country [2]. Adopting tourism as a tool for development in Third World countries therefore requires a global assessment of tourism that should take into account the local context in which it is applied. This is so because tourism highly relies on the macro-economic conditions at the global and national levels that are inherent to its success and that are also deeply rooted in the national and international policies which are totally independent of the tourism industry.

This sad truth about tourism in Third World countries has, in some ways, transcended the tourism phenomenon. Today, tourism is not just a mere leisure activity; tourism has gradually transformed into a fighting tool against social and economic inequalities and global environmental deterioration.

Today, alternative tourism or sustainable tourism is advocated by the national community and organisations fighting against poverty as a remedy to curb poverty and social injustices in Third World countries. However, a question remains: is alternative tourism an effective tool for the development and improvement of the living conditions of local communities in Third World countries?

Community-based tourism, a sustainable tourism approach, constitutes a means to achieve development in Third World countries. Studying community-based tourism and development in Third World countries requires us to identify tourism as a factor of change at the social and economic levels, and as a factor of exchange at the cultural level. Its income-generating attributes and its economic significance to national economies should not overshadow the social and cultural implications that it induces and that are of great importance as far as development is concerned. It is only in this way that tourism can successfully articulate the development of rich nations to the underdevelopment of Third World countries [4]. Tourism develops itself in the framework of a globalised world, thereby helping the local communities to gain an openness to the world capable of strengthening their capacity to better understand the problems they are dealing with and to better identify their needs. However, these local communities are faced with some major impediments that hamper development within their environment. Two of the principal problems faced by Third World countries is the disarticulation of the economies and the domination of foreign multinational companies [5]. Third world countries also suffer from political and institutional issues, problems of lack of resources, social ostracism and marginalisation to some extent. For tourism to be a profitable and successful tool for development in Third World countries, there must be an overall development of the country itself [6], and this "overall development" should follow a bottom-up approach from the pauperised local rural areas to the regional and national levels. Community-based tourism is an approach that follows this bottom-up principle and that tackles, in some ways, poverty issues at the bottom, thus empowering the local communities and generating place revitalisation to fuel a development process. 
The concept of community-based tourism arises from the principle of commitment and community ownership, advocated by sustainable tourism, which is in line with a logic that considers community participation as paramount to the tourism activity for the success of local development and for poverty alleviation [7]. Therefore, the interconnection between the exogenous and endogenous forces that community-based tourism generates provide a fertile ground that promotes community consultation and that extricates them from the isolation pattern in which development is almost impossible. This also helps to bring to light their needs and preoccupations in order to find sustainable solutions for them and to initiate place revitalisation. However, the success of this interconnection fully relies on the effective function and knowledge transfer between the tourist or exogenous force and the community or endogenous force. The influential role played by the local institutions of these communities is also of prime importance to the success of development in the perspective of place revitalisation through community-based tourism. This research examines the case of the Bamiléké zone through the study of the Batoufam chiefdom, a local and traditional rural institution involved in community-based tourism and development within its realm.

\section{METHODOLOGY}

The methodology used in this study relies on theoretical and practical research. The theoretical research entails a bibliographic work on topics related to the geography of tourism, Third World country economics, new economic models for poverty alleviation in Third World countries, and a bibliography on tourism in Cameroon and on the Bamiléké zone of Cameroon.

The theoretical approach also entailed research into the tourism activity in Cameroon and, more precisely, in the Bamiléké zone. This required carrying out a search in the national archives of the Ministry of Tourism and of the Cameroon National Institute for Statistics.

A careful analysis of scientific articles looking at tourism's influence on the improvement of the living conditions of local communities in Third World countries has also been made. The theoretical analysis helps us to develop an understanding of the following dimensions:

- The progress of the tourism phenomenon in the world and the disparities between the northern and southern hemisphere as far as tourism is concerned.

- The mechanisms and the social and economic realities of Third World countries in order to identify the real problems that inhibit development.

- The ability to identify, with the help of some economic theories, the development framework that is suitable for community-based tourism to successfully serve as a tool for development in Third World countries.

- An analysis of the Cameroonian tourism context and its economy, to have a better understanding of the functioning of the Bamiléké society and chiefdoms.

The practical part of this research entailed a qualitative approach towards the question of community-based tourism and local development. This qualitative approach involved a series of semi-directive interviews conducted within the field of research with professionals of tourism, specialised researchers on tourism and development in Africa, Cameroonian government officials and chiefdom representatives. These interviews were conducted from 2012 to 2017.

The main objective behind the practical analysis was to check, on the field, the validity of the hypothesis identified in the theoretical work. This practical part also involves a study of the relevance of the different stakeholders that community-based tourism mobilises in order to have a better understanding of the stakes and challenges that underpin it. These 
stakeholders are the tourists, the non-governmental institutions, the local communities and the government.

\section{COMMUNITY-BASED TOURISM AND PLACE REVITALISATION PATTERN}

Community-based tourism is a type of tourism that is conceived, managed and supplied by the local communities of a given territory. These indigenous communities are the principal stakeholders of the activity and are at the centre of the cultural exchange and the tourism hospitality. Community-based tourism calls for the collective will of a local community to promote natural resources and cultural heritage for the improvement of living conditions. This gives rise to community projects involving services like catering housing and cultural activities like ecotourism for tourists, in exchange for financial compensation to fund local community development projects. The success of community-based tourism relies on the massive and extensive community participation in its development process. Local communities must take part in all the planning steps of community-based tourism to help them get a better understanding of development through capacity-building and empowerment. For community participation to be successful, there needs to be a management structure, an organism or institution at the local level, to identify the needs of the local communities, to define the objectives to be achieved for development and to coordinate the actions undertaken by the local communities as far as community-based tourism is concerned.

Community-based tourism stands in alignment with the logic of endogenous development that is far from the conventional industrial tourism pattern. It tackles poverty issues within the local communities by upgrading capacity development and it also calls for community ownership and cultural re-appropriation. Capacity development is a principle that fully relies on human capital. Human capital is the overriding principle of community-based tourism because it provides the foundation for the emergence of local initiatives [8]. Human capital is a combination of some of the different features that characterise individuals: motivation, entrepreneurial spirit, perseverance and leadership skills. These aspects are put forward in local initiatives undertaken by the local communities. It is the consolidation of the different local initiatives undertaken by the local communities within their environment that instigates the development process at the social, economic and cultural levels and leads to place revitalisation. For place revitalisation to be successful, the local communities must share a common vision or goal, which is the foundation upon which initiatives are undertaken.

\section{THE PRINCIPLE OF ENDOGENOUS AND EXOGENOUS INTERCONNECTION}

Community-based tourism calls for the mobilisation of endogenous and exogenous resources and participatory governance. The exogenous forces are tourist and international institutions like non-governmental organisations (NGOs), and the endogenous forces are the local communities and the government.

It is the meeting of these two forces that generates an exogenous and endogenous interconnection on which community-based tourism depends on. This interconnection occurs in the form of formal and informal contact between the two forces [8], and thus propels the following three-stage process [9]:

- Awareness: This is brought about by the tourist, an exogenous force within the local community, who plays the role of the "awakener" in the mechanism of local community development. The endogenous forces, or local communities, gain awareness on the fact that they can rely on their own strength and capabilities to meet their expectations, that they need to handle their own problems to be able 
to find lasting solutions for themselves and acquire the technical know-how and knowledge on problems management.

- Responsibility: The local communities assume and acknowledge the responsibility of their involvement and actions in the development process. The local community, with the help of technicians, will come together to try to find solutions to the problems identified by the awakeners and that the communities can easily solve by themselves.

- Mentoring: The exogenous force (tourists who are also technicians or teachers, scientists, engineers and experts), who can provide technical solutions to solve the problems, plays the role of technicians in the exogenous and endogenous interconnection pattern. They provide solutions through a mentoring process to the communities on the problems for which they want a solution. This helps the communities to achieve empowerment and capacity-building to tackle development strategies and policies. Empowerment and capacity-building are important prerequisites to community participation.

A few researchers state that some of the elements that promote community participation are the effectiveness of relationships between the exogenous and endogenous forces that go beyond commercial considerations and the putting into place of organisational processes leading to cultural, social and economic development. The local enterprises that mobilise social capital serve as springboards to new community development initiatives [8].

The interconnection between the exogenous and endogenous forces is a cyclic process that should nurture the local initiatives undertaken by the communities. This interconnection calls for partnership mechanisms and networks that require the intervention of local institutions [8].

However, a major obstacle to the success of the exogenous and endogenous interconnection principle is the heterogeneity of the local communities in Third World countries [7]. In most cases the indigenous communities are heterogeneous. The heterogeneity and divergence in their opinions and values can be a hurdle to acquiring a uniqueness of vision, and this uniqueness of vision is the foundation for development policies. This therefore calls for the creation of local structures capable of properly handling the needs and aspirations of the communities or for the collaboration with existing traditional institutions (for example, chiefdoms, etc.) capable of influencing and bringing the communities to a consensus. These traditional institutions represent one of the endogenous forces on which community-based tourism relies on. This research seeks to examine the role and influence of traditional institutions as an endogenous force to place revitalisation enhancement; however, first it is necessary to have a look at the role played by the different stakeholders that partake in the exogenous and endogenous interconnection principle.

4.1 The role played by the different stakeholders that partake in the exogenous and endogenous interconnection principle

- The endogenous actors

- The local communities

o Intervene during the introduction of development proposals concerning their region

o Set the acceptable limits for change within their community

o Participate in the conception of tourism projects with tourism operators 
o Construct, together with the relevant stakeholders, a mechanism for consultation and community development for a better understanding and identification of the expectations and needs of the local community [10]

- The government

o Possesses legislation and regulation powers

o Possesses an incentive power

o Takes care of territorial planning and land use

o Provides infrastructures for development

o Establishes charters or official standards

o Controls tourism flows

o Handles the decisional processes relating to tourism management and development on the territory of local communities

- Role of NGOs

o Create a network for stakeholders to encourage exchanges on topics relating to tourism, bring together people to work in collaboration on local and international projects

o Educate tourists and tourism stakeholders on the question of tourism impact through the publication and spreading of learning resources on the topic

- The tourist

o Encourage a fair tourism between the host communities and tour operators

o Help put in place income-generating micro-projects

o Gathers information on the tourist destination and integrates himself to the local community (that is, learning the culture, getting closer to the communities)

o Has the responsibility to provide his uttermost contribution to the local economy

o Has the responsibility to show respect for the beliefs and customs of the local communities

\section{THE CASE OF THE BAMILEKE ZONE OF CAMEROON}

The Bamiléké zone is located in the West Region of Cameroon. It shares boundaries with the North-West Region and the Adamaoua Region in the north, the Littoral Region in the south, the Central Region in the east and the South-West Region in the west. According to the projections of the Cameroonian National Institute for Statistics for the year 2015, the population of the Western Region of Cameroon is estimated to be 1,921,590 inhabitants, comprising $47 \%$ men and $53 \%$ women, and $57 \%$ of the population living in rural areas. Agriculture is the main activity and $89.9 \%$ of the population is involved in the informal sector. The West Region has a dynamic population and is the second most densely populated region of Cameroon. The population of the Western Region of Cameroon are Semi-Bantous. This population is made up of two main groups: the Bamiléké and the Bbamoun. The Bamiléké population occupy seven of the eight divisions that make up the Western Region.

The Bamiléké society attaches a great importance to their customs and traditions, which are part and parcel of their civilisation. These customs and traditions have a great ancestral value and they regulate, in some ways, almost all social aspects of the life of the local communities. The Bamiléké zone is also made up of chiefdoms, and these chiefdoms are very strong and powerful traditional institutions. The Bamiléké society is considered to be one of the greatest examples of some of the most remarkable traditions and political organisations that one can encounter in African civilisation [11]. 


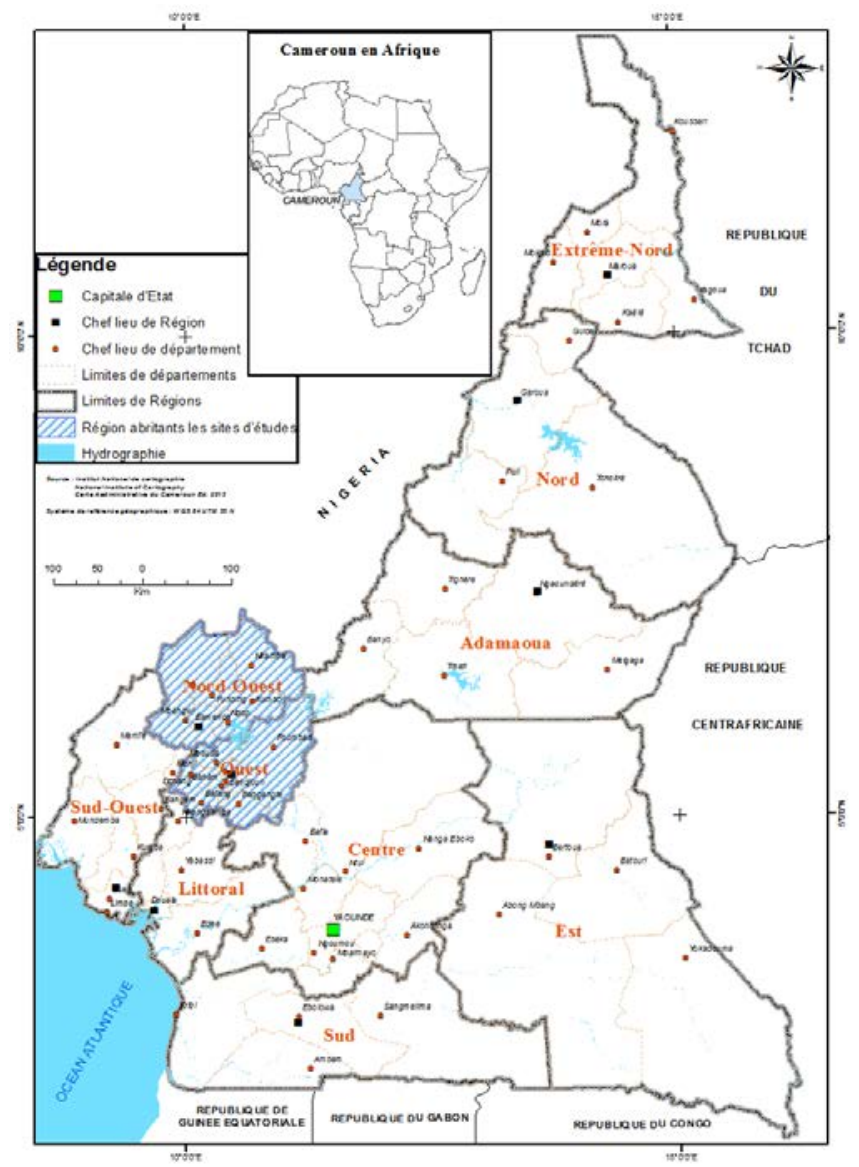

Figure 1: Map of Cameroon with the North and Western region in blue. (Source: Cameroonian National Institute of Cartography, 2017.)

In the Bamiléké society the chiefdoms are powerful traditional institutions in which the chief is almost considered as a sacred, inviolable and semi-divine being. He is the mediator between men and the divined ancestors. He possesses supernatural powers and, therefore, earns the respect, honour and loyalty of the local community.

5.1 The organisation of the traditional administration or chiefdoms in the Bamiléké society

- The chiefdom: Since its existence in the 14th century, the Bamiléké population has always had a hierarchical, traditional administration, and has always been headed by a chief known as Fo. The chiefdom is the highest level of traditional power in the grass fields. The chief or Fo is the decision-maker for all aspects that influence the chiefdom [12].

- The different members of the chiefdom's court and their function.

- The Fo (Mfon, Mfo, Fon): He is the senior chief and he holds the political, administrative, judiciary and religious powers in his hands. He is the first traditional administrator. 
- The assistant: The assistant is the half-brother of the chief. He receives the same traditional and mystical education as that of the chief in the Lâ'Kam - the traditional bush school.

- The court dignitaries (Mkam, Nkom/Nji): These are specific subjects to the chief who have gained their title thanks to their contributions to the development of the tribe, their bravery and their status as chief of their lineage. They are members of one or many secret societies that sit weekly at the chiefdom. They participate in all development projects of the local communities.

- The deputy chiefs (Fothiè, Fo'tio, Mefuo): These are former senior chiefs or prominent dignitaries named by the chief. Their function is to govern the land.

- The ruling family: These are all the descendants of the chiefdom since the creation of a village. The chief's wives, princes and princesses, the chief's mother and the queen mother (Mafo).

- The army: Today the chief's army is not as influential as it was in the inception of the creation of chiefdoms before and after the colonial period. Today it has been reduced to spies, warriors and officers.

- The employees of the chiefdom: These are servants, members of the chief's office, the chiefdom's technicians (carpenters, bricklayers, cooks, loggers/fallers, etc.), great notables and the spouses of the chief.

- The chief's distinguished subjects (great warriors mediums).

- The chief's common subjects: These are the inhabitants of the village.

- The slaves: The pre-existing slaves within the Bamiléké chiefdoms up to the 19th century. Today, slaves do not really exist, except for a class of men known as the LapVep. The difference between the Lap-Vep and the ordinary slaves is that they have agreed to provide voluntary work to the chiefdom.

5.2 The influence of chiefdoms as an endogenous force for development through community-based tourism

The chiefdom as a traditional and local institution plays an important role to development as an endogenous force within the local communities of the Bamiléké society. The chiefdom's influence on the local communities lies in the hands of the chief who concentrates all powers. In light of the principle of endogenous and exogenous interconnection as far as community-based tourism is concerned, the chiefdom plays the following role:

- The centraliser of the community's needs: The loyalty of the local communities of the Bamiléké society to their chief is based on blind trust. No one within the local communities can be dishonest to the chief. Their loyalty to the chief surpasses and even challenges that of the local authorities. The indigenous populations are more likely to report their problems and needs to the chief rather than resorting to state representatives or institutions. As a result, the chief centralises the needs of the local communities and transmit them to the organisations or the bodies in charge of development within the village. This process helps to bring to light the pressing needs of the local communities which, therefore, constitute the basis upon which development strategies can be conducted.

- The mediator of the community and the exogenous forces: The chief is the intermediary between the community and the exogenous forces that enhance development (cultural organisations, NGOs, foreign organisations, the village diaspora). The chief's influence on the local communities makes it difficult for NGOs 
or foreign organisations involved in development to undertake development projects without consulting the chief. He is the voice of the chiefdom and of the local communities and is the bridge between those endogenous communities and the exogenous entities.

- Unifying element: The chief brings consensus to the diversity of needs of the local communities and the proposals of the foreign or exogenous entities. He is the binding bond between the endogenous and exogenous forces. His experience in problemsolving, his running and administrating capacities and his link to the communities give him the necessary expertise and skills to bring both forces to a common agreement. Therefore, he closes the gap that might exist between the communities and the exogenous forces at the cultural level and the perceived values.

- Protection of the community and its heritage: The chief, together with his court, sets the standard that regulates the life of the chiefdom and that of his subjects. Outsiders to the chiefdoms are requested to abide by the rules and regulations of the chiefdom. These rules help to preserve the culture and tradition of the chiefdom which are a historical heritage of great importance. They also help to develop a certain level of respect for the chief and a mutual respect amongst the subjects. As a result, this helps to create a certain degree of order and limits conflicts that can arise between endogenous and exogenous forces. These qualities of the chief make the chiefdom a vital element to development in the exogenous and endogenous interconnection process. However, the influence of these aspects to the success of community-based tourism depends on the chief's dynamism and involvement in development and on his vision and commitment to the local community. The case of the Batoufam chiefdom is a good example.

5.3 The case of the Batoufam chiefdom and its influence as an endogenous force for development through community-based tourism

The Batoufam chiefdom is located in the Bayangam district and in the Koung-Ki district in western Cameroon. The Batoufam chiefdom has a surface area of $172 \mathrm{~km}^{2}$, has 12 cantons and a population of about 30,000 inhabitants. It is a tourist site for its remarkable architecture. The Batoufam chiefdom is indeed an eco-museum of architecture and has been labelled as the museum of "architecture, power and social cohesion". As far as tourism is concerned, the Batoufam chiefdom provides guestrooms for tourists who wish to stay in the chiefdom. Majesty Nayang Toukam Innocent is the actual chief. He is the 16th chief since 1989. The Batoufam chiefdom has existed since the 19th century.

The role played by the chief in the Batoufam development process and in communitybased tourism is as follows:

- The chief of the Batoufam chiefdom works together with the Batoufam elites to set out development programs for the Batoufam chiefdom and the surrounding villages. They develop projects that are meant to promote education amongst the local communities and to improve the living conditions of the local communities (for example, access to water, construction of health centres, etc.).

- The chief has created an international network by keeping links with the Batoufam diaspora, NGOs, diplomatic entities and passing tourists. The chief relies on this network for financial support to fund development projects in the Batoufam chiefdom.

- The chief, together with the regional tourism office, the Batoufam diaspora and elites and the participation of foreign institutions, has helped develop the "Museum of 
Architecture" the label by which it is identified. The Batoufam development committee, together with the chief, have financed the restoration of traditional and cultural buildings and the construction of four guest houses, a restaurant, a royal pond and a handicraft workshop for the tourists. The tourists pay an entrance fee to visit the museum. The money is used for the running of the museum.

The Batoufam chiefdom is one of the most dynamic chiefdoms of the Bamiléké zone. Its chief is focused on development and is very committed to developing his village and the livelihoods of the local communities.

\section{CONCLUSION}

The influence of the traditional institutions in the exogenous and endogenous interconnection through community-based tourism cannot be understated. The case of chiefdoms in the Bamiléké zone of Cameroon is a good example of the relative importance of these institutions

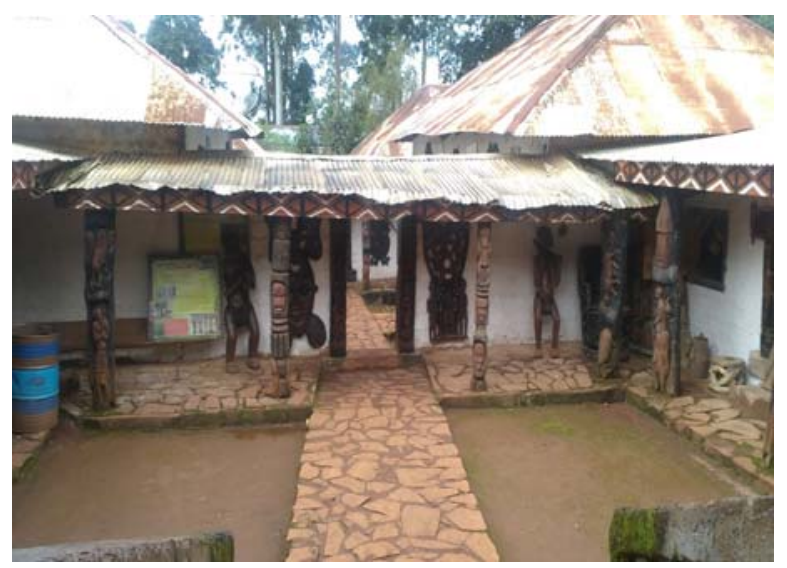

Figure 2: Picture taken within the Batoufam chiefdom, the first entrance leading to the chief's palace. (Source: Terencia Ngono Mindzeng, 2017.)

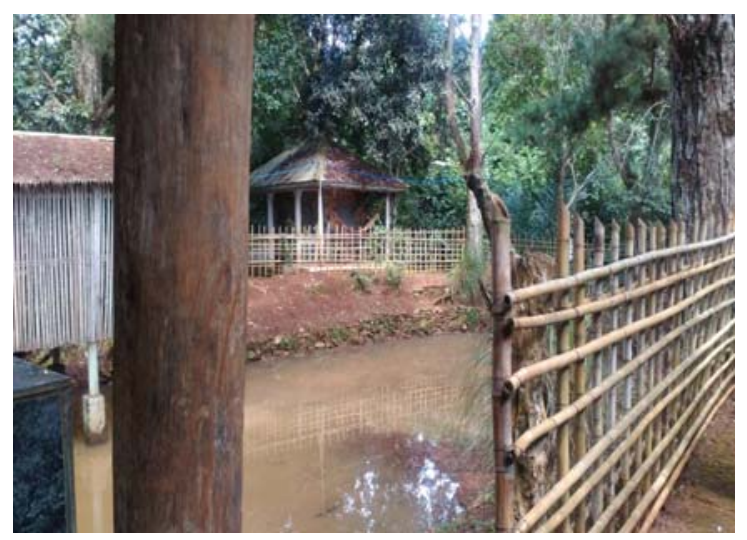

Figure 3: Picture of the royal pond created by the Batoufam people under the chief's initiative. (Source: Terencia Ngono Mindzeng, 2017.) 
as far as local community development is concerned. They are the basis for decision-making, participatory governance and for planned action, and they also provide a harmonised framework upon which development project and programs can be successfully undertaken. They help to transform the heterogeneous and divergent needs, opinions and values into uniqueness of vision, which thus becomes the foundation for development policies. However, in the case of the Batoufam chiefdom, the state does not play its role as a development accelerator; instead, the development efforts undertaken by the chief and the elites are hampered due to corruption and the state's disengagement. The state does not provide enough visibility to the chiefdom in order to boost tourism and development. The development effort at the Batoufam chiefdom is the initiative of the chief, the diaspora, foreign organisations and local communities.

The Batoufam chiefdom, however, still remains a good example of place dynamisation through capacity-building and community development, in spite of the state's lack of involvement.

[1] Mowforth M. \& Munt I., Tourism and Sustainability, Development, Globalization and New Tourism in the Third World. Routledge Taylor \& Francis Group: London and New York, 2009, PhD thesis.

[2] Rousset C., Le tourisme comme instrument d'empowerment des communautés locales du Sud, reflexions sur la cooperation international au développement, Universita degli Studi di Roma "La Sapienza, CIRPS - Centro Interuniversitario in Sviluppo Sostenibile, Doctorat en Développement Durable et Coopération Internationale, 2009.

[3] Cazès G., Tourisme et tiers monde un bilan controversé, Les Nouvelles Colonies de Vacances, 1992.

[4] Françoise Lanfant M., Le tourisme dans le processus d'internationalisation, anatomie du tourisme. Revue Internationale des Sciences Sociales, XXXII, 1980, UNESCO.

[5] Albertini J.M., Les mécanismes du sous-développement et développement. Economie et Humanisme, working editions, 1966.

[6] Ascher F., Tourisme société transnationale et identités culturelles, 4 October 1984, UNESCO.

[7] Delisle M.A. \& Jolin L., Un autre tourism est il possible, 2007 Presses de l'Université du Québec, scientific article.

[8] Parent S., Klein J.-L. \& Jolin L., The local community development and the community-based tourism: a comparative conceptual analysis ESSACHESS. Journal for Communication Studies, 2009.

[9] Mindzeng Terencia N., Community based tourism and development in Third World countries: The case of the Bamileke Region of Cameroon. 20th International Conference on Sustainable Tourism Strategies, Development and Management, 25-26 January 2018, World Academy of Science, Engineering and Technology. International Journal of Social and Business Sciences, 12(1), 2018.

[10] Swarbrooke J., Sustainable Tourism Management. CABI Publishing, 1999.

[11] Tardits C., Contribution à l'étude des populations Bamilékés de l'ouest Cameroon. Edition Berger-Levrault, L'Homme d'Outre Mer Collection Publiée par le Conseil Supérieur des Recherches Sociologiques outre-mer et par J'Office de la Recherche Scientifique et Technique Outre-Mer, 1960.

[12] Toukam D., Histoire et anthropologie du people Bamiléké. Revised and expanded edition. l'Harmattan, 2016. 